\title{
Ensino de língua, o calcanhar de Aquiles da linguística
}

\author{
Language Teaching, Achilles' heel of Linguistics
}

Onici Claro Flôres

Universidade de Santa Cruz do Sul - UNISC - Santa Cruz do Sul - Brasil

\begin{abstract}
Resumo: O presente artigo discute as atribuições dos professores de linguística e de língua portuguesa de acordo com seu contexto de atuação profissional (professores pesquisadores, professores universitários e professores de escola) e sua responsabilidade quanto ao ensino de língua materna na educação básica. Ao mesmo tempo, reconhece a falta de intercâmbio entre universidade-escola e de efetividade do ensino de língua nas escolas públicas brasileiras, levantando algumas hipóteses sobre o motivo causador do atual estado de coisas. Para finalizar, sugere que, no seu espaço de atuação regional, as universidades passem a se preocupar com pesquisa em ensino, ocupando-se ainda com o acompanhamento e a orientação aos professores das escolas, no que respeita ao ensino de língua, no ensino fundamental e médio.
\end{abstract}

Palavras-chave: linguística, ensino de língua, produção de materiais de ensino.

Abstract: The present paper discusses the responsibility of the Linguistic and Language researchers regarding to language teaching, considering the lack of exchange between university-school and the lack of effectiveness of language teaching at elementary and secondary school, raising some hypotheses about the reason of these issues. Finally, it is suggested that universities should regionally concern about research in teaching, as well as the monitoring and guidance to teachers of elementary education, with respect to Portuguese language teaching in Brazil.

Keywords: linguistics, language teaching, materials production for teachers. 


\section{Introdução}

Segundo a lenda grega, Aquiles, filho do rei Peleu e da deusa Tétis, tornou-se invulnerável quando, ao nascer, foi banhado pela mãe nas águas do rio Estige. Apenas o calcanhar por onde Tétis o segurou não foi molhado e continuou vulnerável. "Algumas variantes dizem que Aquiles foi flechado no calcanhar por Páris, que conhecia seu segredo. Mas não há citações em Homero sobre a morte do herói", diz o mitólogo Henrique Murachco, da Universidade de São Paulo. https://super.abril.com.br/ 31/10/2016.

Este artigo propõe uma reflexão um pouco mais detida a respeito de uma pergunta recorrente dos acadêmicos do curso de Letras a seus professores. A pergunta é: como aplicar as teorias linguísticas abordadas no curso ao que é lecionado na escola básica? Ao ouvir essa pergunta, na verdade, já aguardada, os professores buscam fornecer algumas pistas e dar alguma orientação. Caso o professor da vez saiba como fazê-lo, cria um material de ensino relativo à sua aula e o explora didaticamente do ponto de vista de alguém que visa a um leitor/redator infantil ou juvenil, pedindo aos acadêmicos para ajustarem o olhar e fazerem 0 mesmo com outro conteúdo por ele indicado. Em suma, o professor indagado a respeito de como agir $\mathrm{e}$ sobre o que ensinar na educação básica tenta responder à pergunta de seus alunos universitários através da produção de materiais de ensino que vinculem a teoria estudada, no momento, ao ensino escolar de língua, sobretudo, através da proposta de exercícios de leitura - compreensão/interpretação.

Porém, mesmo com algumas demonstrações, que o professor considera esclarecedoras, os alunos persistem afirmando que se sentem inseguros sobre como se comportar e o que fazer. O recurso é produzir uns tantos exemplos de aplicação de propostas teóricas que, após, são replicados de alguma maneira a partir do que foi feito pelo professor. A inexperiência, porém, é grande, e os acadêmicos, mesmo conhecendo a teoria desenvolvida nas cadeiras frequentadas, comumente não conseguem propor objetos de aprendizagem não replicados, ou seja, materiais de ensino que busquem sanar algum problema detectado por eles mesmos, entre os estudantes do ensino básico das turmas visitadas, no estágio de observação.

No cenário acadêmico, então, a indagação sobre o que e como ensinar língua na escola emerge quando os acadêmicos de Letras começam seu estágio de observação, ao se depararem com escolas e alunos reais, passando a se ver na posição de professores. A pergunta expressa, pois, a perplexidade dos universitários diante da incompatibilidade aparente entre o que estudam e aquilo com que se defrontam na prática, não tendo eles a mínima ideia de como teorias linguísticas intrincadas, recheadas de uma terminologia pouco usual, podem se transformar em materiais destinados ao ensino básico. Além disso, as teorias linguísticas de que se fala se contrapõem entre si e, na verdade, uma surge para mostrar a incompletude da outra, salientando suas falhas, criticando-a.

Por isso mesmo, na ótica de jovens (ou não tão jovens) acadêmicos, inseguros, preocupados, existe uma distância abissal entre o que estão estudando e a prática escolar, sendo a incompatibilidade mais do que evidente, no seu modo de ver, sobretudo, porque a metalinguagem das teorias é densa, complexa. Os universitários se perguntam e perguntam a seus professores qual 0 modo ou os modos possíveis de relacionar teoria e prática, de vez que a escola persiste ensinando morfologia e sintaxe, propostas e ensinadas de maneira dissociada. Em decorrência, se solicitados a pensar sobre ensino de língua e sugerir alguma alternativa de aplicação dos conteúdos de linguística trabalhados ao ensino básico, a primeira estratégia a que recorrem é utilizar a nomenclatura usada na cadeira, de modo direto, sem filtro algum.

De sua parte, o professor do curso de Letras pressionado a dar alguma resposta, ou se esquiva e diz que o tema de que trata é inadequado para o ensino fundamental e médio, ou dá uma pausa na matéria a ser desenvolvida no semestre e propõe uma discussão a respeito de possíveis aplicações dos conceitos trabalhados em sua disciplina. Pondera, já de início, ser inadequado fazer a ligação direta entre o que é ensinado na universidade e o material a ser 
usado na escola. Essa ponderação alerta os acadêmicos, mas não os impede de recorrer inicialmente à estratégia de transposição pura e simples. Justificam-na dizendo que é preciso renovar o ensino, a começar pela terminologia.

Ocorre, porém, que a metalinguagem científica a ser empregada na escola tem de ser considerada com muito cuidado, uma vez que os hipotéticos alunos para os quais os universitários precisam preparar materiais desconhecem a linguagem técnica da área a não ser aquela em que são iniciados pelo(s) professor(es) de português de sua escola, não sabendo o que fazer nem o que entender, se o estagiário usar expressões como signo linguístico, verbos performativos, operador argumentativo, atos de fala, ou termos como coesão, pressuposição, diacronia, implícito, polifonia, diglossia, e muitos outros.

\section{A questão da metalinguagem}

Como visto, o primeiro problema com que se defrontam os acadêmicos é aquele referente à metalinguagem. A linguagem das teorias que estudam não é a mesma linguagem do dia a dia, e os estudantes passam bastante tempo tentando equacionar a questão do significado em relação a cada uma das vertentes teóricas a que são apresentados durante o semestre. Para consegui-lo, usam a linguagem comum, tentando afanosamente desentranhar conceitos intrincados de sua rede conceitual e, mesmo assim, por vezes não são bem sucedidos. Logo, para os acadêmicos, a maior dificuldade é a de captar as diferenças entre pontos de vista teóricos, a partir da terminologia usada nas várias vertentes de estudo enfocadas. Em função disso, define-se o que seja metalinguagem como sendo o modo típico de autorregular as formas de expressão e de comunicação das línguas naturais (REY DE- BOVE, 1997).

Parece bem simples, não é? Quase óbvio. Todavia não é suficiente relacionar o conceito de metalinguagem à linguagem da ciência, porque a linguagem comum exige explicitação também, até porque não é transparente/autoevidente. Em decorrência disso, faz-se necessário esmiuçar um pouco mais o conceito de metalinguagem que tanto implica desdobrar, desentranhar, explicitar o querer dizer da terminologia científica quanto ao dizer da linguagem comum, envolvendo também conhecer em detalhes a linguagem própria dos grupos de trabalho ou de lazer e entretenimento para poder participar da interação - jogo, brincadeira - sem se sentir excluído, 'por fora'. Além de tudo isso, a reflexão metalinguística envolve considerar os variados modos como o comportamento linguístico/semiótico é interpretado pelos indivíduos envolvidos na interação considerada, ou seja, é imprescindível ter consciência do contexto em que se dá a interação.

Em suma, a dimensão metalinguística da linguagem relaciona-se à negociação de sentidos e aos usos sociais da linguagem que, diga-se de passagem, nunca são desinteressados e neutros, seja no que diz respeito à construção do conhecimento, seja no que respeita à apreensão da realidade (FLÔRES, 2011). As ciências, de modo geral, burilam seus conceitos e utilizam palavras diferenciadas (terminologia) exatamente para caracterizar a construção teórica realizada pela teoria A ou B, distinguindo-a da linguagem do dia a dia, 0 que exige da construção teórica grande refinamento linguístico, para explicitar o ponto de vista construído, intra e inter teoricamente.

Levando-se em conta o exposto, um dos papéis centrais da metalinguagem é o de resolver dificuldades de entendimento, sanar dúvidas, detalhar informações, situar espaço-temporalmente os eventos, ou seja, a metalinguagem trata de precisar sentidos. E, sem dúvida, esse conceito não interessa somente à linguística, ou à linguagem ordinária. A reflexão concernente à significação da linguagem é decisiva para entender como se estruturam as relações sociais e como é produzido o conhecimento em qualquer instância social, área de estudos ou ciência.

No que diz respeito ao conhecimento gerado na academia, importa analisar o modo como se explicita ou implicita o conhecimento, uma vez que 
sem a possibilidade de usar palavras comuns para criar ou explorar conceitos, a pesquisa não existiria. $\mathrm{Na}$ verdade, as palavras usadas nas teorias adquirem determinados valores, transformando-se em metalinguagem. Essas palavras constituem redes de ideias, de conceitos, que precisam ser considerados no interior da perspectiva analisada em cada caso, exatamente, com o auxílio da linguagem comum. Nessas circunstâncias, a circularidade intrateórica permite atentar para a relação entre linguagem e metalinguagem, de modo focal, o que deixa entrever o modo de construção da perspectiva teórica em análise.

Assim, a terminologia, ou seja, as palavras usadas em cada teoria científica, acabam se afastando da linguagem que a maioria das pessoas entende, sendo substituída por palavras e expressões pouco ou nada usuais, implicando isso a necessidade de o aprendiz/neófito dar conta do conhecimento linguístico e terminológico requerido, se quiser lidar/utilizar a teoria, por exemplo, adequando-a e aplicando-a ao ensino. Em decorrência de tudo isso, a metalinguagem acaba variando de acordo com o contexto (DASCAL, 2006), vinculando-se o recurso à metalinguagem, bem como a atividade desencadeadora da reflexão/explicação ao contexto em que a teoria vai ser ou é utilizada. O que remete, outra vez, à diferença entre os contextos - acadêmico e escolar.

Por outro lado, como bem o assinalou Parret (1988), a operação/atividade metalinguística, quando vinculada à ciência, objetiva repetir e repetir-se, atestando a própria validade. Nesses casos, a repetição é indicada e valorizada, porque fornece um ponto de apoio/referência aos investigadores/usuários/professores que utilizam uma dada teoria. Em outras palavras, como afirma Orlandi: "Toda ciência tem de ter uma metalinguagem, pela qual [estabeleça] suas definições, conceitos, objetos e procedimentos de análise" (ORLANDI, 1999, p. 16).

3 E as crenças, onde elas se inserem, demarcando os contextos de uso da metalinguagem A ou B?
Em vista disso, há que referir que "nenhuma instituição ou relacionamento humano pode ser adequadamente entendido, a menos que consideremos as suas expectativas, valores e crenças" (BREEN, 1985 p. 136). Assim, a questão das crenças, embora sempre evitada e postergada, precisa ser levada em conta, caso se queira entender um pouco melhor o que acontece no contexto do ensino de língua. Nesse sentido, o que se constata é que cada um dos contextos de atuação dos docentes (pesquisadores, universitários e professores de escola) é povoado por determinadas crenças, e que cada um dos grupos envolvidos na situação alimenta uma dada crença, dadas as exigências de trabalho com que se defronta no seu cotidiano, no contexto em que atua. Daí decorre ser inquestionável que as crenças/pressupostos grupais interferem no modo de tratamento da língua e no seu ensino, quer se queira ou não admitir.

Em decorrência disso, antes de o pesquisador sugerir o que fazer, ou, antes mesmo, de entabular uma conversa sobre o que ensinar, talvez valesse a pena debater com os próprios professores do ensino básico o motivo pelo qual trabalham do modo como trabalham. Ou por outra, antes de qualquer outra medida é preciso discutir as crenças do grupo, pois mesmo sendo o estudo das crenças transferido sine die, ou então, embora mudando o nome, para lhe dar uma roupagem mais científica, ao empregar, por exemplo, a expressão pressupostos teóricos, parece que não há como ir adiante sem essa primeira negociação, não havendo como evitar que o problema se apresente.

A busca de enfrentamento da variável 'crenças' foi empreendida por europeus e americanos, a partir dos anos 80. Estes iniciaram essas investigações e desde então muitos estudiosos se integraram ao grupo de interessados. Dentre os pesquisadores envolvidos citam-se Horwitz (1985), Gardner (1998), Wenden (1987). Já no Brasil, as pesquisas sobre crenças iniciaram nos anos 90, destacando-se dentre os trabalhos produzidos os de Barcelos (2000), Félix (1999), Gimenez (2001), Silva (2005), Conceição (2004). 
Ou seja, ainda que a contragosto, a ciência teve de admitir a introdução da variável 'crença' em suas investigações. $\mathrm{Na}$ literatura brasileira a respeito do tema, Silva (2005) definiu crença como um acervo vivo de verdades individuais ou coletivas, na maioria das vezes implícitas, (re)construídas ativamente nas experiências, as quais guiam a ação do(s) indivíduo(s) e podem influenciar o comportamento (crenças) de outros, quer estejam ou não inseridos no contexto situacional. Será que é possível alterá-las? Pelo menos de acordo com Coelho (2006), as crenças são algo como "teorias implícitas, assumidas com base em opiniões, tradições e costumes, teorias que podem ser questionadas e modificadas pelo efeito de novas experiências" (COELHO, 2006, p. 128). Isto é, na ótica de Silva (2005) e Coelho (2006), já citadas, as crenças podem ser modificadas a partir da interação, isto é, por influência de outras ideias/pessoas ou através de novas experiências.

A conclusão das autoras referidas no parágrafo anterior sugere a interação, a aproximação entre os grupos que defendem perspectivas diversas como uma saída para a falta de diálogo e/ou o embate entre crenças diferentes. Segundo as pesquisadoras, a interação próxima e efetiva pode até modificar modos de pensar e agir muito rígidos e repetitivos. O primeiro passo é estabelecer um patamar a partir do qual interagir. A interação proposta ou almejada pressupõe que todos os membros dos grupos possam ser ouvidos e tenham suas opiniões respeitadas.

Com base nisso, pode-se ponderar que se todos os professores envolvidos na situação de ensino de língua tiverem a possibilidade de explicar e admitir seus pressupostos/crenças e entenderem que representam uma matriz de pressupostos que dão sentido ao mundo, não sendo, apenas, "[...] reflexo da realidade, mas [ao contrário] [...] [são] construídos na experiência, no percurso da interação com os demais integrantes desta realidade" (SADALLA, 1998 p. 34), o problema da incomunicabilidade entre os contextos de trabalho dos docentes que ensinam língua portuguesa do Brasil, até poderão ser enfrentados com produtividade. Isso porque, parece bem evidente que os vários grupos envolvidos no processo de ensino de língua e linguística alimentam pressupostos/crenças diferentes.

É importante, além do mais, frisar com base nas ideias de Vygotsky (1991), que as crenças relacionam-se com as línguas, uma vez que as habilidades cognitivas e as formas de estruturar 0 pensamento não são determinadas por fatores congênitos, mas resultam das atividades praticadas de acordo com os hábitos sociais da cultura em que o indivíduo está inserido. Em consequência, a história da sociedade na qual a pessoa se desenvolve e a sua história pessoal são fatores cruciais, determinantes de seu modo de pensar (e de entender o real).

Por isso mesmo, faz-se necessário entender melhor o contexto em que acontece o ensino de língua na escola pública e analisar todas as variáveis que o afetam. Só depois disso, os grupos de professores universitários e pesquisadores poderão manter uma interação fecunda, real, com os professores de escola. Talvez o momento atual possa auxiliar nisso, já que mais do que nunca as duas pontam do processo educacional precisam interagir mais proximamente para poderem se conhecer melhor e produzir algo em conjunto.

\section{A linguística ensinada nos cursos de Letras e o ensino escolar de língua portuguesa do Brasil}

As discussões sobre a precariedade do ensino de língua nas escolas da rede pública atravessaram décadas e continuam acaloradas. O tema ficou repetitivo e já virou "assombração". Na verdade, a persistência do ensino gramatical normativo nas escolas brasileiras é histórica e tem resistido a várias tentativas de adequação à evolução da ciência linguística.

As tentativas de que se fala são gestadas pelos órgãos governamentais responsáveis, sendo introduzidas por distintos gestores públicos, em diferentes épocas da história do país, através de documentos orientadores e, apesar de sua diversidade e do trabalho concomitante de preparação de multiplicadores, até o momento, não 
obtiveram muito êxito. Mesmo os documentos mais atuais (PCNs), em que pese sua constante menção em pesquisas acadêmicas na área das humanidades, não conseguiram mobilizar as escolas de modo significativo.

Esses documentos, todavia, foram produzidos por pesquisadores de renome nacional, não sendo, pois, quaisquer orientações, mas orientações discutidas e recomendadas por especialistas em suas áreas. Assim, as considerações até aqui desenvolvidas, ainda que breves e incompletas, permitem concluir com outros autores que, do ponto de vista político (SALOMÃO, 1997), a ciência linguística se impôs ao ensino universitário de Letras, no Brasil, a partir dos anos 70. Isso é indiscutível, porque há trabalhos investigativos importantes desenvolvidos Brasil afora, os quais circulam bastante no meio universitário, sobretudo, entre estudantes de mestrado e doutorado em Letras. É necessário aditar, entretanto, que, se do ponto de vista político a linguística ganhou espaço e credibilidade, do ponto de vista de sua interface com o ensino de língua, ela nunca chegou a deslanchar do modo esperado.

Em vista disso, a comparação entre os contextos de ensino (acadêmico e escolar) é indispensável, pois faz emergir, de imediato, a diferença entre o que é ensinado em cada um deles, evidenciando o viés analítico proposto à diferença de metalinguagem existente. Saber o que acontece em um e outro contexto é o passo inicial, indispensável para encontrar um ponto de aproximação. Sem essa tomada de consciência do deslocamento de uma perspectiva para outra, a experiência propiciada pelo estágio de observação perderia o sentido, servindo apenas para constatar o que já se sabe.

Após o estágio de observação é inquestionável que os acadêmicos dão-se conta da distância existente entre o ensino universitário e o ensino escolar. Ao mesmo tempo, intuem e podem compreender, também, caso sejam levados a refletir, que é impossível fazer a transposição direta da teoria linguística para o ensino de língua a ser desenvolvido na escola. Essa conclusão é importante, mas não é tudo o que os acadêmicos têm de fazer.
Se a distinção entre o que é ensinado nos dois contextos aqui considerados é crucial, também é importante analisar o papel do professor de linguística e de língua no seu local de trabalho e, ainda, o papel da metalinguagem (e qual é utilizada) em cada um dos contextos de atuação. A hipótese aqui formulada é a de que talvez o confinamento do conhecimento linguístico nas universidades se deva à dissociação entre teoria e prática ou, mais precisamente, aos distintos modos de trabalhar a e com a língua nos dois contextos em análise - a academia subdividida: 1) em curso de graduação e 2) pós-graduação stricto sensu e a 3) escola pública - ensino fundamental e médio. Assente o estabelecimento da divisão de tarefas existente, faz-se a seguir um inventário das atividades de cada grupo de professores em ação no ensino de língua e linguística.

\subsection{Os contextos de atuação}

Começa-se pela menção ao trabalho do pesquisador da área de linguística que investiga temas de seu interesse e, também, ministra aulas nos cursos de mestrado e doutorado sobre esses mesmos temas. Sua maior responsabilidade/preocupação diz respeito à produção de conhecimento, sendo que sua produção acadêmica é acompanhada e avaliada por órgãos federais (CAPES e CNPq) de modo constante e rigoroso. Suas pesquisas podem voltar-se ao ensino, mas não de modo obrigatório. Hoje em dia, esse professor também ministra aulas no curso de graduação, o que implica conviver estreitamente com alunos de três níveis educacionais distintos, adequando o ensino a públicos e interesses diversos. O exercício da docência no curso de graduação é relevante para o pesquisador, porque lhe possibilita maior proximidade com grupos variados de alunos e docentes, bem como maior intercâmbio de ideias e saberes e uma visão clara das necessidades de pesquisa mais prementes, ou seja, dos problemas de pesquisa a serem enfocados em suas próximas investigações. 
Como profissional, o professor pesquisador dedica-se a suas investigações e, em geral, caso não tenha interesse especial em ensino (enquanto campo de aplicação de suas pesquisas) não se preocupa em adequar seus achados a este ou aquele grupo de estudantes que não os seus. Seu interesse em testagens resume-se a comprovar a adequação de suas hipóteses investigativas e a replicabilidade de sua pesquisa, caso seja empírica. Em vista disso, o tempo de trabalho do professor pesquisador é alocado para leitura, escrita e análise de dados e essas tarefas demandam trabalho, dedicação $e$ envolvimento para serem bem sucedidas.

Quanto ao professor universitário que atua na graduação, durante a maior parte de seu tempo de trabalho, este também tem formação avançada, tendo realizado cursos de mestrado e/ou doutorado. Em geral, porém, não atua em ensino no mestrado e doutorado e nem necessariamente faz pesquisa, não tendo de prestar contas de sua produção de conhecimento em termos de número mínimo de artigos científicos produzidos e publicados em revistas acadêmicas ranqueadas, nacional e/ou internacionalmente. Esse profissional concentra suas atividades em ensino, porém ministra várias disciplinas a diferentes grupos de alunos. A diversidade de disciplinas garante de certa forma que revise e atualize seus conhecimentos teóricos, tendo em vista as frequentes reformas de ensino e o rodízio das disciplinas acadêmicas entre os professores.

Em geral, o professor universitário leciona conteúdos de distintas correntes teóricas da linguística de acordo com a cadeira ministrada por ele no curso. Assim, pode lecionar Fonética e Fonologia, Morfologia, Sintaxe ou Morfossintaxe, Semântica, Pragmática, Teorias do Texto e do Discurso e assim por diante. Se lecionar morfossintaxe evita a famigerada divisão do ensino de língua entre morfologia e sintaxe (forma e função linguísticas), que tanto interfere no entendimento textual (cotexto), entre os estudantes universitários. Evidentemente, pode fazer pesquisa, caso o decida. Por vezes, trabalha com extensão, buscando aproximar a universidade da comunidade local, uma parte essencial do trabalho acadêmico que constitui o tripé da universidade - ensino, pesquisa e extensão.

De outra parte, em 2007, através do Ministério da Educação, o governo federal propôs a criação do PIBID (Programa Institucional de Bolsas de Iniciação à Docência), que oferece a possibilidade de interrelacionar os cursos de licenciatura com as escolas, envolvendo todos os implicados no processo educacional: os professores de escola, os acadêmicos, os professores universitários e os alunos do ensino básico. A intenção do programa é unir as secretarias estaduais e municipais de educação e as universidades, contribuindo para a melhoria do ensino nas escolas públicas, sobretudo, daquelas em que o Índice de Desenvolvimento da Educação Básica (Ideb) esteja abaixo da média nacional, de 4,4. Esse programa tem dado ótimos resultados em algumas universidades, reunindo, de fato, três perspectivas de trabalho em função da melhoria do ensino. Os alunos pibidianos, como costumam ser chamados, têm muito mais clareza e discernimento, quanto ao que utilizar no ensino, segundo a orientação dos professores que desempenham a função de coordenadores das atividades de inter-relação universidade/escola. Talvez o único senão esteja em os acadêmicos deixarem para depois a sua própria formação, desistindo por antecipação da perspectiva de aprofundamento teórico possibilitada pela pesquisa da área, por se preocuparem com a produção de materiais de ensino e sua boa apresentação, ao invés de buscarem dar-lhe maior consistência teórica etc.

Já o professor do ensino fundamental e médio, em geral, leciona português a vários grupos de alunos; seu trabalho, praticamente, se resume a dar aulas. Caso tenha 20 horas, cumpre dezesseis horas ministrando aulas. Se for um professor de 40 horas, dobra o número de turmas e aulas a serem ministradas. A atividade principal do professor de escola é a docência. Esse professor não costuma considerar profunda e detidamente 0 material que está utilizando para dar suas aulas. Se o considera razoável, utiliza-o, sem pensar duas vezes. Como as escolas públicas, em geral, adotam livros didáticos, os professores os utilizam como guias da matéria a 
ser lecionada. As tarefas de falar, demonstrar, explicar, reexplicar, acalmar os alunos (crianças e adolescentes) envolve um corpo a corpo muito intenso, o que leva esse professor a não se envolver muito com o estudo/investigação da matéria a ser dada nem com o seu aprofundamento, pensando ele, sobretudo, na diversificação dos materiais de ensino para estimular o interesse dos alunos. Quando decide estudar não costuma fazê-lo por conta própria, investindo em cursos de especialização ou mestrado, inclusive para melhorar sua condição profissional.

O professor de escola tem aguda consciência de que precisa revisar e reorganizar o ensino com cuidado. Talvez por isso, até para não se perder, prefira usar materiais que ele mesmo organizou ao longo dos anos, os quais repetem os conteúdos de morfologia e sintaxe constantes em vários livros didáticos já consultados. De fato, não sabe e nem se propõe/atreve a fazer uma mudança profunda, radical, no material de ensino que usa por se sentir desatualizado, uma vez que as teorias linguísticas seguem seu curso, avançando continuamente. Quanto a ele, acaba por se fixar no modo de trabalho que o grupo de professores de língua da escola em que atua se apoia, o que não the exige esforço demasiado nem muitos confrontos com os colegas, por vezes utilizando (com exclusividade) o livro didático para ministrar suas aulas. No tocante à leitura, com certeza recorre ao livro didático. Isso acontece porque mesmo que tenha organizado um banco de textos durante o seu curso de graduação, esse banco de textos e tarefas só vai poder ser utilizado se a escola dispuser de computadores suficientes ou de 'verba' para reprodução de textos (para todos os alunos e turmas da escola em que leciona). No ensino público, isso é uma quimera!

Desse modo, a análise das atribuições e rotinas dos professores de linguística e de língua dos dois contextos (embora incompleta e relativamente superficial) permite concluir que o mundo da escola e o mundo da academia são mundos com práticas e envolvimentos diferentes. Como, então, alterar os hábitos e rotinas já estabelecidos? Costumeiramente, o recurso tem sido convocar os pesquisadores das universidades para propor mudanças, pois os professores de ambos os contextos reconhecem que é a pesquisa que permite a evolução do conhecimento.

Assim, quando se discute ensino de língua e sua inoperância são chamados especialistas em linguística que apresentam teorias inovadoras, as quais, mesmo sendo consideradas interessantes pelos professores que assistem às palestras, não são utilizadas para ensinar nas escolas. Os professores assistentes aplaudem e se entusiasmam, mas a rotina cumpre seu papel e tudo permanece na mesma. O motivo de a rotina persistir talvez seja a mesma razão que imobiliza os estudantes universitários no momento de aplicar a teoria estudada ao ensino. A metalinguagem é muito densa e eles não sabem como relacionar alhos com bugalhos, afinal uma coisa é uma coisa e outra coisa é outra coisa.

Em decorrência, "tudo segue como dantes no quartel de Abrantes", porque mesmo sendo indiscutível que, do ponto de vista das pesquisas sobre linguagem, a linguística tenha se sobreposto aos estudos da filologia, cujo foco de investigação gramatical se restringira à morfologia e à sintaxe frasal, nada ou quase nada mudou no ensino de língua do país, que persiste centrado na gramática da palavra e da frase, nos moldes tradicionais há pelo menos 50 anos. Além do mais, não há por que nem como negar que os estudos gramato-filológicos foram e são fundamentais, ainda que os filólogos, como afirma Salomão (1997), não tivessem se proposto a abordar o português ou qualquer outra língua do modo abrangente e detalhista como o fez a linguística, através de suas diferentes correntes teóricas.

Com base no exposto, há que considerar que talvez o desdobramento da linguística em linguísticas, cada corrente de estudo enfocando um objeto próprio, isto é, algum ângulo de análise específico e bem definido da língua/texto/discurso, além de utilizar uma metalinguagem específica, seja uma das possíveis causas do afastamento do professor (atuante em sala de aula na escola) da linguística e motive a sua 
persistência num tipo de ensino que já domina ou pensa dominar.

A ciência linguística, como se sabe, evolui, aliás, como qualquer outra ciência, e está sempre acrescentando novos problemas e questionamentos ao já sabido, buscando ir além. É bem provável que o professor de escola se sinta desorientado, confuso, com a extensa e pródiga proliferação de enfoques teóricos. Em primeiro lugar, sente-se sempre devedor, uma vez que não consegue acompanhar a evolução do conhecimento linguístico de modo a obter uma visão geral do assunto, como, por exemplo, fazem os professores dos cursos de graduação, que nem sempre fazem pesquisa, mas alternam as disciplinas lecionadas, o que os leva a fazer um rodízio de leitura sobre as diferentes correntes de estudos linguísticos. O professor de escola, porém, não tem como acompanhar as inovações teóricas da linguística sem orientação e se dá conta de tudo o que lhe falta saber, sentindo-se despreparado para aprender o que desconhece de modo independente.

Enfim, o que se pode concluir a partir do exposto até aqui é que o professor de escola leciona Língua Portuguesa, no Ensino Fundamental, ou Língua Portuguesa e Literatura no Ensino Médio ou, então, alfabetiza. Ele não leciona linguística e por isso seu conhecimento a respeito vai se deteriorando e se esvaindo sem qualquer utilidade prática, pois ele não sabe como relacionar o que sabe de linguística ao ensino. Esse professor, na verdade, não pode nem deve focalizar apenas gramática, ou leitura ou escrita. Ele precisa trabalhar com as quatro habilidades linguísticas - falar, ouvir, ler e escrever. Em suma, ele ensina língua (língua materna) para crianças e adolescentes.

Como diz Salomão (1997), a descontinuidade entre estudos linguísticos e formação pedagógica tem profundas raízes históricas que atestam que, se a ciência linguística evoluiu, sua aplicação pedagógica não foi captada ou, então, não foi aplicada, devidamente, quer por parte dos professores, quer por parte dos materiais didáticos disponibilizados pelo governo. O fato é que os professores de língua persistem preferindo usar materiais de ensino tradicionais, que abordam tópicos gramaticais isolados, dissociados entre si, dissociando, ainda, o ensino de gramática das atividades de leitura e de escrita propostas.

Por que, então, os livros didáticos não apresentam conteúdos mais atualizados? Eis um problema a ser discutido. Por outro lado, será que o professor escolheria o material mais atualizado ao invés daqueles mais tradicionais? Em suma, parece haver um buraco negro na área de ensino, um vácuo entre a formação universitária em Letras e a docência no ensino básico.

\section{Que conhecimentos de linguística introduzir no ensino básico?}

De início, há que reconhecer que nem todos os estudos linguísticos são aplicáveis ao ensino. Há teorias e teorias e muitas delas não têm relação com a prática pedagógica, de modo imediato. Além disso, é possível investigar sobre leitura. Ou apenas sobre escrita. Ou, ainda, sobre construções gramaticais, e assim por diante. Em outros termos, a pesquisa pode enfocar um objeto de investigação circunscrito, limitado. No ensino é diferente. Há que pensar na linguagem em sua totalidade - dando prioridade à verbal, mas não excluindo as demais. Em que pese tudo isso, há conhecimentos oriundos da linguística que têm grande importância para o ensino de língua.

Para começar, um dos ensinamentos fundamentais é o de que há quatro habilidades linguísticas: falar, ouvir, ler e escrever. Então, se são quatro habilidades, há que haver preocupação educativa com as quatro e não com uma apenas. De início, as crianças precisam interagir e para tanto falar e ouvir. Estas são habilidades naturais. Ler e escrever, por outro lado, não são naturais, são habilidades que precisam ser aprendidas.

Todavia, ainda que distintas e irredutíveis, as habilidades de falar, escutar, ler e escrever mantêm entre si vínculos importantes, havendo inter-relação entre elas. Assim, embora falar seja uma habilidade natural e ler uma habilidade aprendida, para aprender 
a ler é preciso relacionar a escrita à fala, emitindo o fonema correspondente ao grafema, para conseguir ler. Ademais a escrita é uma representação da fala. Em vista disso, no ensino de língua, a prática das quatro habilidades linguísticas e o conhecimento de suas inter-relações é indispensável, precisando ser valorizado e posto em prática.

Por exemplo, crianças bem pequenas, mesmo não falando ainda, precisam ouvir seus cuidadores, mãe, pai e irmãos falarem, conversarem, dirigirem-se a elas para que passem a integrar o grupo e possam dominar a fala, interagindo com os demais membros do grupo. Na maternal e na Pré-Escola aparecem outros protagonistas: a professora, as atendentes, os coleguinhas. O mundo social da criança vai-se expandindo e ganhando novos contornos. Como uma criança vai saber o que e como dizer, se não conseguir ouvir o que os outros dizem? Antes de aprender a ler, de outra parte, é preciso que fale e fale organizadamente, expressando as ideias com certa clareza e continuidade. Falar bem, emitindo os fonemas da língua materna com clareza, é uma habilidade precursora da leitura, pois ler, como já salientado anteriormente, implica transformar 0 grafema (letra) em fonema, pareando o que foi escrito com o som correspondente ao da fala, daí a interrelação entre fala e escrita. Dessa forma, articular a fala sem muitos atropelos, repetições, descontinuidades e rupturas é essencial para aprender a ler. Expressar o querer dizer até o fim, sem lacunas que prejudiquem o entendimento do que está sendo dito, também, sendo que as crianças precisam ser orientadas a se expressar, a dizer o que sentem, a contar uma história, a ouvir uma leitura, a esperar seu turno de fala e assim por diante. Nesse campo, há muito a fazer, muito a aprender e ensinar. E sobre a iniciação escolar da criança no estudo de língua(gem), o que se pode dizer? O que comentar a respeito da introdução da criança no mundo da escrita? O que tem a linguística a ver com isso?

$\mathrm{Na}$ verdade, a introdução do conceito de fonema é uma contribuição fundamental da linguística à formação dos professores de língua, em geral, e, em particular, à formação de alfabetizadores. Dessa forma, ainda que abstrato e distante de noções de língua(gem) que os falantes nativos já possuem de modo intuitivo e natural, o conceito de fonema é essencial para o ensino/aprendizado da leitura/escrita iniciais. O motivo dessa necessidade nem sempre compreendida é que o sistema de escrita do português é alfabético e por isso demanda que o iniciante apreenda a inter-relação fala/escrita, por ele pressuposta. Em vista disso, embora não seja produzido isoladamente pelo falante, e nem se embase no senso comum, tem de ser estudado, analisado e manejado com proficiência pelos alfabetizadores.

Porém, e sempre há muitos "poréns" no Brasil, o trabalho com o fonema foi (quase) banido das escolas. Assim, como os professores que alfabetizam não são licenciados em Letras, mas em Pedagogia, em geral, começam a trabalhar a partir da palavra, utilizando o chamado método global. A opção massiva pela palavra como um todo criou uma barreira contra a utilização do método fônico, dado como retrógrado e sem criatividade. Ao que se saiba, há uns 20 ou 30 anos, pelo menos, os alfabetizadores optaram por abandonar o estabelecimento da relação grafema/fonema, deixando de orientar seus alunos em relação ao modo de estruturação da sílaba e da palavra. Desde então passaram a trabalhar como se bastasse ler (reconhecer) palavras já sabidas (decoradas), eliminando uma etapa essencial do ensino/aprendizado do modo de funcionamento da escrita e de ensino de leitura.

Além disso, o que, na verdade, agrava ainda mais o problema, não são todas as universidades brasileiras que incluem em seus cursos de Pedagogia, disciplinas de linguística. Em decorrência, um aspecto imprescindível da formação de leitores foi abandonado - o do inter-relacionamento entre fala/escrita. Os anos passaram e o resultado da experiência de eliminação do vínculo fala/escrita, ao longo de várias décadas, evidencia-se hoje em números. Praticamente, duas ou três gerações de maus leitores passaram a engrossar as estatísticas sobre o atual número de analfabetos funcionais. 
O que se reitera enfaticamente, contudo, é que a necessidade de trabalhar com a decodificação/codificação não significa apenas optar por um método de ensino e nem é uma decisão negociável. O que se destaca é que para a maioria absoluta dos leitores iniciantes não há como aprender a ler sem apreender o princípio alfabético, e para apreendê-lo é preciso praticar muito, mecanizando o processo de decodificação. Mecanizar o processo, contudo, não significa repetir a mesma estrutura, do mesmo modo, com todos os alunos, todos os dias da semana, do mês e do ano. Há que variar as estratégias de ensino, testar outras combinatórias, enfim, ir adiante, sem pular etapas decisivas. Nesse aspecto, os jogos de linguagem podem ser de extrema valia (DIEHL; FORNECK, 2017), auxiliando os professores a incrementar a emergência da consciência fonológica dos iniciantes em leitura, a partir da pré-escola.

Outro aspecto do ensino de língua em que a linguística já interferiu e pode interferir positivamente ainda mais é através da "expansão e validação social de formas e usos [da linguagem] tratados tradicionalmente como "desvios" e "erros"” (SALOMÃO, 1997, p. 142). Sem dúvida, dentre os estudos linguísticos importantes estão os variacionistas, que trouxeram uma lufada de ar fresco para o ensino de língua, propiciando um trabalho escolar menos engessado, mais aberto às variedades linguísticas existentes. De fato, tudo na língua obedece a determinadas regras que não precisam se basear nas normas da gramática normativa ou naquelas contidas em outro manual qualquer, mas nos usos sociais de uma dada língua, no caso, o português do Brasil. Em suma, tudo na língua é sistemático e convencional, basta esclarecer a que sistema e a que convenção se está reportando o trabalho feito e em que nicho social se pode utilizá-lo.

Se isso é verdadeiro, também é verdadeiro que os professores, ainda que se expressem em um português (brasileiro) marcado por suas origens sociais, persistem exigindo a norma gramatical tradicional, quando a tarefa é produção escrita. A maioria já desistiu de igualar a fala à escrita, apenas reclamando daqueles usos dialetais mais discriminados e rechaçados, socialmente. O que, é claro, não é recomendável nem aceitável. Quanto à escrita, entretanto, há relatos de casos de obrigatoriedade de uso da norma em situações em que seu emprego até já deixou de fazer sentido como o de uso de ênclise no início do texto/parágrafo ex.: Trouxeram-me/ me trouxeram- cuja inversão é amplamente utilizada por bons escritores nacionais. Esse apego à norma, contudo, pode-se dever ao medo de preparar mal os alunos para enfrentar o mundo do trabalho, que continua funcionando desse modo, segundo o entendem os professores.

Em prosseguimento à enumeração das contribuições da linguística ao ensino de língua, vale mencionar os estudos do texto e do discurso, através de várias teorias, dentre elas as da Linguística Textual, Pragmática, Teoria da Enunciação, Semântica Argumentativa. A linguística textual permitiu o avanço da frase ao texto, fornecendo critérios analíticos: os conceitos de coesão e coerência. A coesão, responsável pela ligação dos sentidos isolados das palavras, vincula-as textualmente de modo a mostrar a tessitura da sequência superficial do texto, não perdendo de vista o todo e a intenção com que foi produzido esse todo, para constituir um texto. Os mecanismos de coesão podem ser utilizados pelos professores para possibilitar aos alunos a apreensão da globalidade textual, ao invés de prosseguirem insistindo apenas na sintaxe frasal. Ou seja, os mecanismos coesivos da referência, substituição lexical, elipse, colocação, repetição, conjunção, se explorados, podem contribuir para uma melhor estruturação do texto, bem como para uma melhor leitura, constituindo importantes contribuições da linguística ao ensino de língua. $O$ conceito de coerência, por sua vez, implica a conformidade entre fatos ou ideias e a sua expressão em palavras, podendo-se associá-la ao processo de construção dos sentidos do texto e à articulação das ideias.

São também relevantes os chamados fatores pragmáticos de textualidade: 1) intencionalidade, que remete à análise do modo como o produtor do 
texto concebeu e expressou suas ideias, a fim de obter o seu objetivo comunicativo em função do receptor, por exemplo, informar, impressionar, convencer, pedir, ofender, etc.; 2) aceitabilidade, que concerne à expectativa do leitor, ao modo de recepção textual, não apenas enquanto indivíduo isolado, mas como alguém que analisa e avalia o grau de coerência, coesão, utilidade e relevância textual a partir do seu lugar social; 3) situacionalidade, que diz respeito aos elementos responsáveis pela pertinência e relevância do texto quanto ao contexto em que ocorre, respondendo pela adequação do texto ao contexto sociocomunicativo em que foi produzido; 4) informatividade - princípio que diz respeito, em especial, à suficiência de dados textuais, bem como ao grau de previsibilidade das ocorrências nele contidas no plano conceitual e também no formal; 5) intertextualidade, que se relaciona à introdução/presença no texto em leitura ou em produção de signos ou ícones que tornam a leitura/produção do texto atual dependente do conhecimento de outro(s) texto(s). A intertextualidade mostra a interdependência dos textos entre si, tendo em vista que um texto só faz sentido quando é entendido em relação a outro texto (COSTA VAL, 2004).

De sua parte, a Teoria da Enunciação enfatiza a subjetividade e a argumentatividade, uma vez que a linguagem é vista a partir do sujeito que a enuncia, estabelecendo-se a partir disso a interlocução. Nessa perspectiva, a linguagem não é entendida apenas como meio de comunicação, mas especialmente como meio de construção da identidade do sujeito. A Teoria da Argumentação na Língua, por sua vez, propõe uma concepção argumentativa da língua, considerando que os sentidos das entidades linguísticas são estabelecidos através de encadeamentos argumentativos. Para Ducrot (1988), a argumentação está na língua e o valor argumentativo é o nível principal da descrição semântica, relacionando-se ao papel desempenhado pela palavra no discurso.

Já a Análise do Discurso notabilizou-se por analisar construções ideológicas presentes em textos.
Nesse sentido, discurso é a prática social da qual resulta a produção de textos, o que implica que todo discurso é uma construção social, não individual, e que só pode ser analisado se considerado seu contexto histórico-social, suas condições de produção; ao mesmo tempo, significa ainda que o discurso reflete uma visão de mundo determinada, necessariamente, vinculada à do(s) seu(s) autor(es) e à sociedade em que vive $(m)$. Essa vertente teórica enfatizou o conceito de contexto, concebido como a situação histórico-social de um texto, envolvendo não somente as instituições humanas, como também outros textos produzidos em seu entorno, com ele relacionados. Pode-se dizer que, nessa acepção, contexto é a moldura de um texto e envolve elementos tanto da realidade do autor quanto do receptor. Em decorrência, a interpretação de um texto envolve saber que há um autor, com determinada identidade social e histórica e, a partir disso, situar o discurso como compartilhando esta identidade.

Mas, perguntam os professores do ensino básico, e a gramática? Como ensiná-la? O que ensinar? Bem, a recomendação dos investigadores contemporâneos é continuar estudando e trabalhando com gramática, de preferência, em textos, segundo vários deles. (MOURA NEVES; CASSEB-GALVÃO, 2014). Essa recomendação, no entanto, é fácil de sugerir, mas não de concretizar, porque trabalhar com morfossintaxe em textos, por exemplo, crônicas, notícias, $\mathrm{HQ}$, charges, bem como vincular o texto ao contexto (pragmática) interpretando-o, envolve horas de trabalho. Disso os professores da graduação entendem bem. A teoria é uma coisa e sua aplicação outra, uma vez que a linguagem dos textos de jornal, digamos, é mais fluida e diversificada do que os modelos fixos e sempre iguais de sintaxe frasal constantes nos materiais didáticos. Enfim, conhecer a teoria é uma coisa e aplicá-la, outra. São trabalhos distintos, ainda que não excludentes.

Os gramáticos da atualidade, na verdade, continuam estudando a língua e suas possibilidades de realização, buscando incluir em suas produções as contribuições da linguística, apresentando-as, entretanto, a partir de diferentes perspectivas. Dentre 
as gramáticas atualmente em circulação, cita-se a gramática de Maria Helena de Moura Neves que afirma que estudar gramática é estudar a vida da língua. Sua Gramática de Usos do Português enfoca a construção textual através dos processos de predicação, referenciação etc. Em suma, a renovação teórica é uma necessidade para todos os profissionais envolvidos no ensino de língua, não havendo como dela esquivar-se. Além de tudo o mais, sem dúvida, distinguir um verbo de um substantivo continua sendo imprescindível, bem como saber conjugar os verbos, inclusive diferenciando o significado de formas verbais homônimas, pertencentes a verbos diferentes. Isso para não acontecer o sucedido na crônica de João Ubaldo Ribeiro, segundo ele o relata, a seguir:

\section{O VERBO "FOR"}

Vestibular de verdade era no meu tempo. Já estou chegando, ou já cheguei, à altura da vida em que tudo de bom era no meu tempo; meu e dos outros coroas. [...]

O vestibular de Direito a que me submeti, na velha faculdade de Direito da Bahia, tinha só quatro matérias: português, latim, francês ou inglês e sociologia, sendo que esta não constava dos currículos do curso secundário e a gente tinha de se virar por fora. Nada de cruzinhas, múltipla escolha ou matérias que não interessassem diretamente à carreira. Tudo escrito tão ruibarbosianamente quanto possível, com citações decoradas, preferivelmente. $[\ldots]$

Quis o irônico destino, uns anos mais tarde, que eu fosse professor da Escola de Administração da Universidade Federal da Bahia e me designassem para a banca de português, com prova oral e tudo. Eu tinha fama de professor carrasco, que até hoje considero injustíssima, e ficava muito incomodado com aqueles rapazes e moças pálidos e trêmulos diante de mim. Um bela vez, chegou um sem o menor sinal de nervosismo, muito elegante, paletó, gravata e abotoaduras vistosas. A prova oral era bestíssima. Mandava-se o candidato ler umas dez linhas em voz alta (sim, porque alguns não sabiam ler) e depois se perguntava o que queria dizer uma palavra trivial ou outra, qual era o plural de outra e assim por diante. Esse mal sabia ler, mas não perdia a pose. Não acertou a responder nada. Então, eu, carrasco fictício, peguei no texto uma frase em que a palavra "for" tanto podia ser do verbo "ser" quanto do verbo "ir". Pronto pensei. Se ele distinguir qual é o verbo, considero-o um gênio, dou quatro, ele passa e seja o que Deus quiser.

- Esse "for" aí, que verbo é esse?

Ele considerou a frase longamente, como se eu estivesse pedindo que resolvesse a quadratura do círculo, depois ajeitou as abotoaduras e me encarou sorridente.

- Verbo for.

- Verbo o quê?

- Verbo for.

- Conjugue aí o presente do indicativo desse verbo.

- Eu fonho, tu fões, ele fõe - recitou ele impávido. - Nós fomos, vós fondes, eles fõem.

Não, dessa vez ele não passou. Mas, se perseverou, deve ter acabado passando e hoje há de estar num posto qualquer do Ministério da Administração ou na equipe econômica, ou ainda aposentado como marajá, ou as três coisas. Vestibular, no meu tempo, era muito mais divertido do que hoje e, nos dias que correm, devidamente diplomado ele deve estar fondo para quebrar. Fões tu? Com quase toda a certeza não. Eu tampouco fonho. Mas ele fõe.

(O Estado de S. Paulo, 23/09/1998)

De todo modo, o que é indispensável, premente, é a mobilização dos grupos envolvidos em ensino e pesquisa linguística, para assim todos poderem contribuir de forma mais efetiva, sobretudo, porque o ensino de língua vai mal, muito mal, sendo urgente melhorá-lo. 


\section{Palavras Finais}

Para concluir, ainda que não se tenha feito um levantamento exaustivo de todas as possíveis contribuições da linguística para o ensino de língua, pode-se afirmar com segurança que a linguística brasileira construiu uma base de conhecimentos sólida e pode contribuir de forma substancial para o ensino de língua, embora a expansão de seus achados sofra impedimentos de variada ordem, além de se ressentir da ação de arraigadas crenças dos professores da escola básica que confiam na gramática da palavra e da frase, enquanto forma mais segura e estável de ensinar língua, no ensino fundamental e médio.

O que entrava o processo de intercâmbio de conhecimentos de um contexto de trabalho para o outro dentre os profissionais envolvidos diz respeito, pelo que se depreendeu da observação feita, à necessidade de criação de um nível intermediário de ação. Constatou-se existir um vácuo entre ensino universitário/ensino escolar, o qual diz respeito, em primeiro lugar, à produção de material para o ensino de linguística, na universidade. Nesse contexto, é necessário pensar na transposição das teorias linguísticas para o ensino de língua, em especial, pois o maior mercado de trabalho para os acadêmicos de Letras é a escola pública. Trata-se de investir na produção de materiais de ensino dirigidos aos estudantes de graduação que não precisam conhecer todos os meandros teóricos de uma determinada vertente teórica, da forma como deve fazê-lo um pesquisador, digamos, mas têm de entender o que constitui a base, o fundamento da teoria A ou B para discernir as diferenças de enfoque entre as várias propostas teóricas em circulação.

Em segundo lugar, é preciso que haja incremento substancial à produção de materiais para o ensino básico, pois sem isso não há como alterar a rotina do professor da escola que precisa contar com opções de trabalho viáveis, exequíveis e de qualidade. Na verdade, os pesquisadores têm de se colocar 'na pele' do professor que dá aulas em dois ou três turnos, para crianças e adolescentes. Este professor precisa de encontros de atualização e de estudo sistemáticos e, também, de materiais de ensino que saiba manejar. Esses materiais, no entanto, devem ser testados, validados, para não se tornarem réplicas fiéis dos livros didáticos atualmente em uso. Talvez os mestrados profissionais possam ocupar esse nicho bastante descurado da produção científica do país.

O certo é que a produção de livros didáticos tal como realizada hoje não está dando conta do problema existente, sendo que o gerenciamento da qualidade dos materiais de ensino parece não dispor de critérios avaliativos que incluam a evolução dos conhecimentos linguísticos nem sua adequação. Não basta incluir aqui e ali alguns termos mais conhecidos de uma ou outra teoria, ou apresentar um grande número de textos de diferentes gêneros, apenas para entreter a gurizada. Os materiais em circulação (boa parte deles) não resistem a uma análise mais fina, pois aquilo sobre o que tratam é morfologia ou sintaxe frasal, pura e simplesmente. Claro, com alguma pitada de semântica através, por exemplo, de exercícios de sinonímia. Em síntese, faz-se necessário investir na qualificação do material de ensino posto à disposição do professor.

Para concluir, uma sugestão: talvez as universidades devessem assumir a função de mediação, no que tange à produção de materiais de ensino em nível escolar, de acordo com sua área de influência regional. $O$ trabalho delas visaria à adequação desses materiais, prestando-se elas também a orientar os professores sobre como usálos. As propostas, por outro lado, precisariam ser validadas e posteriormente avaliadas por quem tivesse experiência na produção de material de ensino e não apenas por pesquisadores de diferentes correntes teóricas. Explicitando um pouco melhor, $\mathrm{o}(\mathrm{s})$ pesquisador(es) que trabalhasse $(\mathrm{m})$ com pesquisa sobre ensino de língua deveria $(m)$ conhecer as teorias linguísticas, de modo geral, e filtrar delas aquilo que pudesse ser aplicado ao ensino. Tais medidas garantiriam que as produções obedecessem a critérios mais claros, possibilitando a validação do estudo feito, caso ele fosse adequado. Assim, se o 
trabalho de aplicação ao ensino fosse aprovado, o material didático poderia ser replicado, aliás, como acontece com toda pesquisa empírica.

\section{Referências}

BARCELOS, A. M. F. Understanding teachers' and students' language learning beliefs in experience: A Deweyan Approach. Tese de Doutorado. The University of Alabama, Tuscaloosa, AL, USA, 2000.

BREEN, M. Authenticity in the Language Classroom. Applied Linguistics. 6 (1): 60-70, 1985.

COELHO, H. S. H. "É possível aprender inglês na escola?" Crenças de professores sobre o ensino de inglês em escolas públicas. In: Crenças e Ensino de Línguas. Foco no professor, no aluno e na formação de professores. Campinas, SP: Pontes Editores, , 2006, p. 125-143.

CONCEIÇÃO, M. P. Vocabulário e consulta ao dicionário: analisando as relações entre experiências, crenças e ações na aprendizagem de LE. Tese (Doutorado em Estudos Linguísticos) - Faculdade de Letras, Universidade Federal de Minas Gerais, Belo Horizonte, 2004.

COSTA VAL, M. G. Texto, textualidade e textualização. In: CECCANTINI, J. L. T.; PEREIRA, R. F.; ZANCHETTA JR., J. Pedagogia cidadã: cadernos de formação - Língua Portuguesa. V. 1. São Paulo: UNESP-Pró-Reitoria de Graduação, P. 113-128, 2004.

DASCAL, M. Interpretação e compreensão. São Leopoldo: Editora UNISINOS, 2006

DIEHL, J.; FORNECK, K. L. A Consciência Fonológica na Formação de Professores. REVELLI - Revista de Educação, Linguagem e Literatura. Inhumas/Goiás, v. 9 n.1 p. 99-123, Maio 2017.

DUCROT, O. Polifonía y argumentación. Tradução de Ana Beatriz Campo e Emma Rodríguez. Cali: Universidad del Valle, 1988.

FÉLIX, A. Crenças de duas professoras de uma escola pública sobre o processo de aprender língua estrangeira. In: J. C. P. Almeida Filho (Org.) O professor de língua estrangeira em formação. Campinas: Pontes, p. 93-110, 1999.
FLÔRES, O. C. (Meta)Linguagem. Linguagem \& Ensino. Pelotas, v. 14, n.1, p.243-261, 2011.

GARDNER, H. Inteligencias Múltiples. La teoria en la prática. Barcelona: Paidós, 1998.

GIMENEZ, T. Learners becoming teachers. An exploratory study of beliefs held by prospective and practicing EFL teachers in Brazil. Tese de doutorado. Lancaster University, 1994.

HORWITZ, E. K. Using student Beliefs About Language Learning and Teaching in the Foreign Language Methods Course. Foreign Language Annals. Vol. 18, Issue 4, p. 333-340. Sept. 1985

MOURA NEVES, M. H.; CASSEB-GALVÃO, V. C (Orgs.). Gramáticas contemporâneas do Português: com a palavra os autores. São Paulo: Parábola Editorial, 2014.

MOURA NEVES, M. H. Gramática de Usos do Português. 2 ed. São Paulo, UNESP, 2015.

ORLANDI, E. O que é Linguística. São Paulo: Editora Brasiliense, 1999 (12 $2^{\text {a }}$ reimpressão)

PARRET, H. Enunciação e Pragmática. Tradução de Eni P. Orlandi, Arco A. Escobar, Maria A. Babo, Paulo Otoni, Raquel Fiad e Rodolfo llari. Campinas: Editora da Unicamp, 1988.

REY DE-BOVE, J. Le Métalangage: étude linguistique du discours sur le langage. Paris: Armand Colin, 1997.

SADALLA, A. M. F. de A. Com a palavra, a professora: suas crenças, suas ações. Campinas: Alínea, 1998.

SALOMÃO, M.M.M. Linguística e Ensino de Português - Variações sobre um tema recorrente. In: PEREIRA, M. T. G. (Org.). Língua e Linguagem em questão. Rio de Janeiro: EdUERJ, p.139-158, 1997.

SILVA, K. A. Crenças e aglomerados de crenças de alunos ingressantes em Letras (Inglês). Dissertação (Mestrado em Linguística Aplicada) Instituto de Estudos da Linguagem, Unicamp, Campinas, 2005.

VYGOTSKY, L.S. Pensamento e Linguagem. São Paulo: Martins Fontes, 1991.

WENDEN, A. Learner Strategies in language learning. NJ: Prentice Hall, 1987.

\section{COMO CITAR ESSE ARTIGO}

FLORES, Onici Claro. Ensino de língua, o calcanhar de Aquiles da linguística. Signo, Santa Cruz do Sul, v. 42, n. 75 , dez. 2017. ISSN 1982-2014. Disponível em: <https://online.unisc.br/seer/index.php/signo/article/view/11442>. Acesso em: doi: http://dx.doi.org/10.17058/signo.v42i75.11442. 